\title{
RAIDOS SUTRIKIMŲ TURINČIŲ ANKSTYVOJO AMŽIAUS VAIKŲ EMOCIJŲ RAIŠKA IR JOS PLĖTOTE் ŠEIMOJE
}

\author{
Liuda Radzevičienė, Nijolė Šostakienė \\ Šiauliu universitetas, Klaipèdos jūrininku ligoninè
}

\begin{abstract}
Anotacija
Straipsnyje pateikiamas tyrimas, atskleidžiantis raidos sutrikimų turinčių ankstyvojo amžiaus vaikų emocinès raiškos šeimoje aspektas. Analizuojama vaikų emocinė būklè ir veiksniai, lemiantys sutrikusios raidos vaikų emocinę plètotę. Nustatyta, kad tarpusavio santykių pobūdis gali kisti tẻvams aktyviai bendraujant su vaiku tiek kokybiškai, ir kiekybiškai. Nustatyta, kad tėvų poveikis, pagrịstas artima situacine emocine interakcija, ne visada veiksmingas, o vaiko artimoji aplinka bazinių emocijų kontekste turètų užtikrinti besiformuojančių psichinių poreikių tenkinimą ir jų plètotę.

PAGRINDINIAI ŽODŽIAI: sutrikusi raida, ankstyvasis amžius, emocinė raiška, šeima.
\end{abstract}

\begin{abstract}
Research presented in the article reveals emotional expressions of early age children with developmental disorders who are brought up in families. In article discussed emotional state and factors that influence development of emotional expression. It is set up that character of relationships could vary depending on the active communication in the aspect of quantity and quality. Parents communication based on the close emotional interaction is not Always successful; and another implication supports idea that child's closed environment must ensure satisfaction of basic emotional reactions in the process of forming and development child's psychosocial needs.

KEY WORDS: developmental disorders, early age, emotional expressiveness, family.
\end{abstract}

DOI: http://dx.doi.org/10.15181/tbb.v68i4.951

\section{Ivadas}

Pastaraisiais dešimtmečiais vykę ankstyvosios intervencijos vaikystëje sampratos pokyčiai atskleidžia perèjimą nuo ị vaiką orientuotos intervencijos prie visapusiškesnio požiūrio, atsižvelgiant ị vaiką, šeimą ir aplinką, ir atitinka platesnę idejų negalès srityje raidą, t. y. perejjimą nuo medicininio modelio prie socialinio (Ankstyvoji intervencija vaikystèje. Europos situacijos analizè. Esminiai aspektai ir rekomendacijos, 2005). Atkreipiamas dėmesys ị šeimos, auginančios neigalius vaikus, problemas. Šeima pripažįstama kaip reikšminga kompleksinès pagalbos vaikui dalis, galinti ne tik padėti vykstant vaiko raidos procesui, bet ir pati būti aktyvi, dalyvaujanti ir kurianti ankstyvosios intervencijos vaikystejje proceso dalyvè (Ališauskienè, 2005; Ališauskienè, Selvenytė, 2004).

Šeimos įtraukimas akcentuoja pagalbos pasidalijimą ir aktyvų šeimos dalyvavimą organizuojant pagalbos teikimą (Dunst, Trivette, Hamby, 2008). Mokslininkai 
(Dunst, Trivette, Hamby, 2008) pateikia klasifikaciją, kurioje ị šeimą nukreipta praktika skirstoma ị santykinę pagalbą (klinikiniai ịgūdžiai: specialistų aktyvus klausymasis, užuojauta, empatija, pagarba ir tikejimas šeimos narių stiprybėmis bei gebejjimais) ir dalyvaujančią pagalbą (individualizuotas, informuojantis, lankstus, atitinkantis šeimos prioritetus ir poreikius procesas). Pastarasis pagalbos modelis yra veiksmingesnis tiek vaiko raidos dinamikos, tiek tėvų aktyvaus dalyvavimo intervencijos procese aspektais (Dunst, Trivette, Hamby, 2008), nes koncepcija pabrèžia šeimos vaidmenį ir jos stiprybes - tai ir yra į šeimą nukreiptos pagalbos teikimo filosofijos esmè.

Kūdikių bendravimas su tèvais prasideda nuo verksmo, šypsenos, generalizuotų motorinių reakcijų, kitų neverbalinių ženklų, siunčiamų artimiesiems kaip poreikio patenkinti psichofiziologinius poreikius signalas (Charles, Zeanah, 2012). Dèl nuolat kūdikio kartojamos elgsenos tèvai atkoduoja jo poreikius ir užsimezga tam tikras abipusis bendravimas, kuris sudaro prielaidas formuotis prieraišumui, emocinei ir kognityvinei plètotei (Juffer, Bakermans-Kranenburg, van Ijzendoorn, 2007). Ankstyvojo amžiaus vaikų, turinčių regos, klausos, motorikos ar kompleksinių raidos sutrikimų, bendravimo, emocinè, kartu ir prieraišumo raida nenatūrali. Jų pirmieji bandymai komunikuoti nèra adekvatūs ịprastai kūdikio raidai, pvz.: aklas kūdikis gali nutilti išgirdęs motinos balsą, tokia nereginčio kūdikio reakcija gali būti neteisingai suprasta kaip vaiko nesidomèjimas aplinka, o ne kaip aktyvus klausymasis ir dèmesingumas iš aplinkos ateinančiai stimuliacijai; cerebriniu paralyžiumi sergančio kūdikio veido mimika, paèmus jị ant rankų, gali būti neteisingai suprasta kaip prisilietimo, padèties keitimo baimės išraiška, o ne kaip tiesiog su raumenų įtampos kaita susijusi problema. Dèl raidos sutrikimų, kurie lydimi sensorinès deprivacijos, kūdikiai taip pat negali adekvačiai ịvertinti tėvų elgsenos, jiems siunčiamų signalų (Charles, Zeanah, 2012). Taigi pirmosios komunikacijos patirtys yra varginančios tiek tėvams, tiek kūdikiams. Akivaizdžiai šie sutrikusios raidos nulemti komunikacijos sunkumai matomi kūdikio emocinèje raiškoje: jiems sunku atpažinti emocijas ir jas identifikuoti kaip siunčiamą informaciją. Taigi kūdikių elgsena gali būti neadekvati situacijai.

Tyrimo objektas: raidos sutrikimų turinčių ankstyvojo amžiaus vaikų emocinių ryšių raiška ir jos plètote šeimoje.

Tyrimo tikslas: atskleisti raidos sutrikimų turinčių ankstyvojo amžiaus vaikų emocijų raiškos ir jos pletotès šeimoje galimybes, taikant situacinès interakcijos programą.

Tyrimo metodai, metodologija ir eiga:

1. Mokslinès literatūros analizè.

2. Keturių savaičių trukmès emocijų raiškos šeimoje stebejjimas ir fiksavimas. 
3. Ekspertinio vertinimo tyrimas, siekiant identifikuoti atitinkamas emocijas pagal šeimų fiksuotą vaikų elgseną.

4. Tikslingas stebejjimas. Remiantis ekspertinio vertinimo atlikta vaikų elgsenos analize ir pateiktomis išvadomis, parengtas stebejjimo protokolas, kur išskirta vaikų elgsena fiksuota dienos laiko ir elgsenos trukmès aspektais.

5. Devynių mènesių situacinė interakcinè programa, skirta emocinei raiškai plètoti.

6. Tyrimų duomenims apdoroti naudotas SPSS neparametrinių statistinių metodų paketas ir Windows Microsoft Exel programa. Dviejų požymių ryšiui tirti taikyta dažnių lentelių analizès procedūra SPSS programos pakete. Kintamujų nepriklausomumo hipotezei tikrinti taikyti neparametrinis suderinamumo kriterijus Pearson testas, naudojant exact funkciją. Nulinè hipotezė atmetama reikšmingumo lygmeniu $p<0,05$.

Tyrimo imtis: tyrime dalyvavo 34 šeimos, auginančios tiek pat raidos sutrikimų turinčių 16-24 mėnesių vaikų. Vaikų raidos sutrikimo diagnozė patvirtinta medicininėmis išvadomis. $\mathrm{N}$ apskrities Ankstyvosios reabilitacijos tarnybas lankančios šeimos tyrime sutiko dalyvauti savanoriškai.

\section{Emocijų raiškos kategorijų išskyrimas}

Remiantis mokslinès literatūros analize (emocijų diferencijavimos teorijos afektiniu kognityviniu konceptu, Изард, 2000, Charles, Zeanah, 2012), vykstant preliminariam stebejimui ir vèliau ekspertinio tyrimo metodu identifikuotos emocijos ir emocinès būklès, kurios išryškejjo kasdienejje vaiko veikloje, tejvams bendraujant su vaiku. Tai: linksmumas (malonus emocinis potyris, kuris kyla pasiekus tikslą, patenkinus poreikị, kartais - be aiškios priežasties); noras bendrauti (tarpusavio sąveika, sudètingi, ịvairialypiai kontaktai, atsirandantys iš bendros veiklos poreikių); krykštavimas (intensyvi, garsinè džiaugsmo emocijos ekspresija); vokalizacijos (neintensyvi garsinè džiaugsmo emocijos raiška ramybès metu); įnoringumas (vaikų elgsenos bruožas - nepaklusnumas, priešinimasis suaugusiujjų reikalavimams; ankstyvojo amžiaus vaikai savo įnoringumą gali reikšti verksmu, šauksmu); irzlumas (neintensyvi, garsinè liūdesio emocija, kuriai būdingas nepasitenkinimo jausmas); vangumas (pasyvi liūdesio emocijos raiška); agresija, nukreipta i kitus (priešiškas elgesys, kuriam būdingas ịžūlus pranašumo demonstravimas ar net jègos naudojimas kito žmogaus atžvilgiu); autoagresija (savęs žeminimas, kaltinimas, žalojimas, ankstyvajame amžiuje tai gali reikštis plaukų tampymu, rovimu, savęs kandžiojimu, galvos daužymu ị sieną, grindis, pan.); stiprus verksmas (intensyvi garsinè liūdesio emocijos raiška); švelnumas, glaustymasis (džiaugsmo 
emocijos raiška, siekiant artimo fizinio kontakto su suaugusiuoju); homeostatine būsena (paslanki kurios nors sistemos - šiuo atveju emocinès - pusiausvyros būsena, išliekanti tol, kol sistema priešinasi pusiausvyrą trikdantiems išoriniams ir vidiniams veiksniams). Kaip paskira elgsenos forma išskirtas stereotipinis elgesys (angl. stereotypy - beprasmis judèjimas, toks kaip plaikstymasis rankomis, galvos sukinèjimas, viso kūno sūpavimasis, intensyvus lankstymasis pirmyn atgal).

Išskirti stebiniai dažnai atskleidžia ne emociją, o elgseną, kuria reiškiasi viena ar kita emocija (autoagresija, vokalizavimas, krykštavimas, verksmas, glaustymasis). Tẻvai stebėjimo metu žymèjo vaikų elgseną, kai vyraudavo viena ar kita emocinè reakcija. Vèliau emocinès reakcijos tyrèjų susistemintos pagal pasirinktą emocijų klasifikaciją. Pavyzdžiui, kaip bazinè džiaugsmo emocijos raiška identifikuotas krykštavimas, linksmumas, vokalizacijos; liūdesio bazinei emocijai priskirtos įnoringumo, stipraus verksmo emocijos. Kaip bazinės pykčio emocijos raiška identifikuota agresijos kitiems ir sau elgsena. Šiame tyrime remiamès agresijos neuroanatominès struktūros teorija (DiMatteo, Robin, 2002) ir agresiją suprantame kaip individo elgesị, veiksmą ar nusiteikimą, nukreiptą į fizinès ar psichinės žalos suteikimą kitam.

\section{2. İ šeimą orientuotos situacinès interakcinės programos metodologinis pagrindimas}

Kognityvinis požiūris ị socialinę interakciją prasideda aksioma, kad žmogus yra protinga būtybė, kurios elgsena nèra atsitiktinè, nulemta refleksų ar instinktų (Eisenberg, Spinrad, 2004; Juffer, Bakermans-Kranenburg, Van Ijzendoorn, 2007; Powell, Dunlap, 2010). Atsakas ị aplinkos stimuliaciją, dirgiklius turi kognityvinę prasmę, kuri daro žmogaus elgseną visuomenėje adekvačia (Kihlstrom, 2012). Taigi situacinès interakcijos visuomenès kontekste suprantamos kaip socialinės interakcijos, o individo komunikacijos lygmenyje jos gali būti ịvardijamos kaip situacinès interakcijos, t. y. siauresnè, spontaniška, lankstesnè, konkretesnè komunikacijos forma. Situacinès interacinès programos esmè tyrime - tėvų elgesio su sutikusios raidos kūdikiais formų, kurios reikšmingos raidos dinamikai, akcentavimas (Juffer, Bakermans-Kranenburg, van Ijzendoorn, 2007; Powell, Dunlap, 2010).

Tèvai, dalyvavę tyrime, bendraudami su sutrikusios raidos kūdikiais turèjo vadovautis programa, kuri numato kūdikių emocinès ir socialinès raidos plètotę, kartu ir emocinių tarpusavio ryšių šeimoje pozityvią dinamiką. 


\section{1 lentelè. Tẻvų ịgūdžiai, skatinantys kūdikių emocinę ir socialinę raidą}

\begin{tabular}{|c|c|}
\hline Tèvų ịgūdžiai & Apibrěžtis, komponentai, pavyzdžiai \\
\hline $\begin{array}{l}\text { Tèvai su vaiku bendrauja spontaniškai, } \\
\text { jautriai, švelniai ir abipusiškai }\end{array}$ & $\begin{array}{l}\text { Tėvai visada ir nedelsdami atsako ị kūdikio } \\
\text { iniciacijas: } \\
\text { - Tėvai tiksliai supranta ir atkoduoja kūdikio } \\
\text { signalus } \\
\text { - Tėvų bendravimas atitinka kūdikio amžių ir } \\
\text { nuotaiką } \\
\text { - Tėvų bendravimas yra ekspresyvus, šiltas ir } \\
\text { ittaigus } \\
\text { •Bendraujant palaikomas abipusis, tolesnị } \\
\text { bendravimą inicijuojantis ryšys su vaiku }\end{array}$ \\
\hline $\begin{array}{l}\text { Tèvai nustato kasdienès veiklos } \\
\text { rutinos modeli }\end{array}$ & Miegas, valgymas, veikla \\
\hline $\begin{array}{l}\text { Tèvai naudoja vaiko elgsenos igūdžius } \\
\text { formuojančias priemones ir apsaugo } \\
\text { nuo negatyvių elgesio apraiškų }\end{array}$ & $\begin{array}{l}\text { Pagyrimų, paskatinimų, dèmesio, pastiprinimo, } \\
\text { situacinių ir planuotų priežasties bei pasekmès } \\
\text { ryšių veikloje, dėmesio perkèlimo / nukreipimo } \\
\text { taikymas, tam tikrų situacijų ignoravimas ir } \\
\text { apribojimai }\end{array}$ \\
\hline $\begin{array}{l}\text { Tèvų skatinimas naudoti pagrindinius } \\
\text { socialinius emocinius igūdžius, } \\
\text { bendraujant su vaiku }\end{array}$ & $\begin{array}{l}\text { Dėmesys kreipiamas ị veidą, įdèmus stebejjimas } \\
\text { žvilgsniu, kartu išlaikomas dėmesys, } \\
\text { aiškūs neverbaliniai ir verbaliniai signalai, } \\
\text { nusiraminimas }\end{array}$ \\
\hline $\begin{array}{l}\text { Tèvai mokomi ir skatinami pasitelkti } \\
\text { socialines kompetencijas }\end{array}$ & $\begin{array}{l}\text { Dalijimasis, pagarba, laukimas, klausimai, } \\
\text { kalbėjimasis, bendradarbiavimas, bendri } \\
\text { žaidimai, konfliktų sprendimas }\end{array}$ \\
\hline $\begin{array}{l}\text { Tėvai mokomi ir skatinami taikyti } \\
\text { emocines kompetencijas }\end{array}$ & $\begin{array}{l}\text { Emocijų identifikavimas ir gebėjimas tiksliai } \\
\text { jas ịvardyti, tinkama jausmų raiška, empatija }\end{array}$ \\
\hline $\begin{array}{l}\text { Tėvų įtraukimas ị pozityvias situacines } \\
\text { interakcijas žaidžiant su vaikais }\end{array}$ & $\begin{array}{l}\text { Pozityvūs žaidimai, ị vaiką orientuoti žaidimai } \\
\text { poroje }\end{array}$ \\
\hline
\end{tabular}

Šaltinis: adaptuota remiantis Powell, Dunlap, 2010.

\section{Raidos sutrikimų turinčių kūdikių emocinių ryšių formavimosi prielaidos ir struktūra}

Evoliucijos požiūriu emocijos reikšmingos tuo, kad jų pagrindu atsirado nauji motyvacijos tipai, sudėtingi elgesio modeliai, jų ịvairovė, emocijos leidžia žmogui puoselèti adekvačius santykius su jị supančiu pasauliu ir sèkmingai prisitaikyti kintančioje aplinkoje (Tronick, 2007; Radzevičienė, 2006). Emocijų kilmės priežastis - kūdikio ir motinos komunikacijos poreikio tenkinimas. Verbalinè suaugusiųjų komunikacija yra pagrindinis socialinių ryšių palaikymo būdas, ikikalbinia- 
me raidos etape būtent emocijos ir jų raiška užtikrina bendravimo galimybę - iš pradžių tik su motina, vèliau - ir su kitais asmenimis (Huebner, Risser, McGiness, Dougherty, cit. Изард, 2000). Kūdikio ir motinos komunikacija pagrịsta emocijomis, sutrikusios raidos kūdikiui ji gyvybiškai svarbi, nes emocijos yra viena pagrindinių ryšio su aplinka priemonių (Benson, Haith, 2009; Juffer, BakermansKranenburg, Van Ijzendoorn, 2007).

Džiaugsmas, neapykanta, nuostaba, baimè, pasišlykštèjimas ir liūdesys - bazinès emocijos, kiekviena jų reiškiasi subjektyvia pajauta, fiziologiniais pokyčiais ir atitinkama išorine elgsena. Taigi emocijos turi ir elgsenos, ir fiziologini komponentą (Изард, 2000; Tronick, 2007; Charles, Zeanah, 2012). Kūdikystès laikotarpiu vaiko emocijų diferencijavimuisi, kartu ir psichosocialinei raidai svarbu patenkinti fiziologines reikmes (Eisenberg, Spinrad, 2004). Esant elementariai adaptacijai, pirminei postnatalinei sensorinei patirčiai, emocinès reakcijos nuo 2 savaičių pradeda diferencijuotis. Dèl patirto streso gimstant, pirmają ir antrają gyvenimo savaitę vyrauja neigiamos emocijos. Kūdikis pradeda adaptuotis prie naujų aplinkos sąlygų, mitybos režimo, aktyviai prisitaiko termoreguliacijos, kvèpavimo, šalinimo fiziologiniai mechanizmai (Radzevičienè, 2006; Tronick, 2007; Zeanah, 2012). Alkio, šalčio, šlapumo pojūčius lydi neigiamos garsinès emocinés reakcijos, ị kurias suaugusieji iškart reaguoja.

Emocinių reakcijų diferenciaciją šiame amžiuje veikia kontaktų su vaiko aplinka kokybė, motorinių ir sensorinių aferentacijų, gaunamų iš vaiko aplinkos, kiekis (Meisels, 2003), taigi esant raidos sutrikimams emocijų diferenciacijos procesas lètēja. Daugelis mokslininkų (Robin, Troy, 2010; Zeanah, 2012) yra linkę manyti, kad kūdikio veidas atspindi jo išgyvenamas emocijas. Nustatyta, kad visame pasaulyje tiek vaikų, tiek suaugusiujų bazinių emocijų raiška vienoda (Изард, 2000). Baimès emocijos raiška yra universali visose kultūrose: plačiai atmerktos akys, pakelti antakiai, atsipalaidavusi ir šiek tiek praverta burna. Bazinių emocijų raiškos universalumas leidžia manyti, kad žmonès, kaip biologinè grupè, turi genetiškai užprogramuotą gebejjimą tas pačias emocijas reikšti ta pačia elgsena (Radzevičienè, 2006). Dar vienas emocijų ịimties įrodymų yra tai, kad nuo 5-6 mèn. vaikų emocijų raiška keičiasi, atsižvelgiant ị ịgyjamą patirtị (kai mamai linksma, ir vaikas tai mato, jis pradeda šypsotis, kai mato motiną nuliūdusią, pradeda raukytis). Taigi veido išraiška tampa patikimu vaiko emocinės būklès vertinimo rodikliu (Zeanah, 2012).

Ryškejjančios emocinès raidos problemos (Robin, Troy, 2010) ankstyvajame amžiuje siejamos su auklëjimo klaidomis ir individualiomis vaiko raidos savybėmis. Žinoma, tai ambivalentinis ir koreliuojantis reiškinys, tačiau esant raidos sutrikimams, emocinè raida nukenčia dèl kūdikio neurologinès būklès nulemtų veiksnių ir tampa antrinio pobūdžio raidos problema (Benson Haith, 2009; Po- 
well, Dunlap, 2010). Kūdikio raida vyksta ypatingomis sąlygomis, ją būtų galima apibūdinti kaip deprivacinę, kai organizmo sensorinès ar motorinès sistemos neturi galimybiu priimti ir integruoti iš aplinkos gaunamos informacijos. Daugelio autorių (Robin, Troy, 2010; Zeanah, 2012; Radzevičienè, 2000) darbai rodo, kad savitai besiformuojantys sutrikusios raidos kūdikių emocinès ir socialinès raidos bruožai lemia žmogaus socialines problemas ateityje.

\section{Raidos sutrikimų turinčių ankstyvojo amžiaus vaikų emocinių ryšių šeimoje tyrimo rezultatai}

Tyrime dalyvavo šeimos, auginančios ankstyvojo amžiaus vaikus, kuriems mediciniškai patvirtintas tam tikras raidos sutrikimas. Vaikų raidos sutrikimų reabilitacijos tarnybas lankantys vaikai turi įvairių raidos sutrikimų (žr. 2 lentelę), tačiau visiems jiems būdingas socialinès emocinès raidos nevisavertiškumas. Tik 14 šeimų augina vieną vaiką šeimoje, kitose dar yra vaikų nuo 1 iki 3 metų. Daugiau vaikų, lankančių Vaikų raidos sutrikimų reabilitacijos tarnybas, yra vyresni, berniukų (21) daugiau negu mergaičių (13). Tyrime dalyvavo laisvanoriškai sutikusios dalyvauti šeimos. Tyrimo imtis neleidžia daryti apibendrinančių išvadų visų Lietuvos Vaikų raidos sutrikimų reabilitacijos tarnybų kontekste, tačiau tyrime atskleistos tendencijos gali būti naudingos atliekant tolesnius tyrimus, ieškant veiksmingos pagalbos būdų, plètojant ankstyvojo amžiaus sutrikusios raidos kūdikių emocinę raidą.

\section{2 lentelè. Tyrime dalyvavusių kūdikių amžius ir raidos sutrikimas}

\begin{tabular}{|l|l|c|}
\hline \multirow{2}{*}{ Raidos sutrikimas } & \multicolumn{2}{|c|}{ Vaikų amžius } \\
\cline { 2 - 3 } & $\begin{array}{c}16-19 \text { mėn. } \\
\text { (atvejų skaičius) }\end{array}$ & $\begin{array}{c}20-24 \text { mén. } \\
\text { (atvejų skaičius) }\end{array}$ \\
\hline Dauno sindromas & 3 & 6 \\
\hline Cerebrinis vaikų paralyžius & 5 & 7 \\
\hline Regos sutrikimas & 1 & 5 \\
\hline Kompleksinis raidos sutrikimas & 3 & 4 \\
\hline
\end{tabular}

Ankstyvajame amžiuje kūdikio emocinę sveikatą lemia jo bazinių fiziologinių ir psichinių poreikių tenkinimas. Psichinių poreikių tenkinimo kokybė sudaro arba nesudaro palankių sąlygų emocinių ryšių ir emocijų raiškos plètotei. Emociniai kūdikių ir tèvų ryšiai gali būti identifikuoti pagal kūdikių emocinę raišką, kuri atskleidžia vaiko psichofizinị patogumą ir gali būti vienas iš optimalios tarpusavio sąveikos rodiklių. 
Tẻvams stebint kūdikių elgseną ir emocijų raišką išskirtos teigiamos ir neigiamos apraiškos, kurios, tèvams taikant situacinio interakcinio poveikio programą, turejjo kisti, t. y. tèvams bendraujant su kūdikiais buvo siekiama platesnès emocijų skalès, kad tèvai greičiau ir tiksliau suprastų vaiko poreikius, reiškiamus atitinkama elgsena bei emocijomis, ir taip formuotųsi adekvatūs tèvų ir kūdikio komunikacijos ịgūdžiai.

Teigiamus emocinius ryšius atskleide tokia fiksuota vaikų elgsena: aiškiai demonstruojamas noras bendrauti su suaugusiuoju, krykštavimas, vokalizavimas bendraujnat, tiesioginių fizinių kontaktų siekis (glaudimasis prie suaugusiojo, noras pasedèti ant kelių ir pan.), linksmumas, teigiamos emocijos, dalyvaujant bendroje su suaugusiuoju veikloje. Po situacinès interakcinès programos, paremtos artimu emociniu ryšiu, nustatyta, kad vyko statistiškai reikšmingi vaiko emocinès būklès pokyčiai (1pav.) ne tik puoselèjant teigiamas emocijas ir ryšius, bet kito ir pati vaikų elgsena.

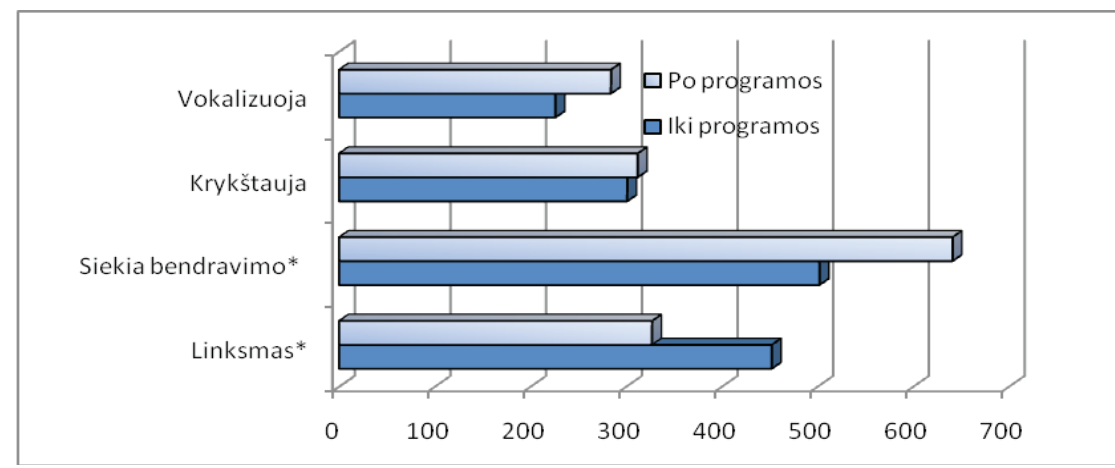

1 pav. Teigiamos vaikų elgsenos ir emocinès raiškos kaita (požymio dažnis) Pastaba: * - elgsenos kategorijų statistiškai reikšmingas kitimas $p \leq 0,05$

Bendravimo su suaugusiaisiais kontekste kito ne tik emocinių ryšių su suaugusiaisiais kokybė ( $p=0,00$, vertinant dinaminiu aspektu), bet labiau diferencijavosi ir emocijos. Iki programos dažniau fiksuotas vaikų linksmumas (emocinis bendravimo motyvas) peraugo ị kokybiškai naują sąveikos formą - bendravimą, paremtą kognityvine motyvacija $(p=0,00)$. Kartu vaikai rodė stipresnius ryšius su tėvais $(p=0,01)$ : švelnumą, norą prisiglausti, pratęsti buvimo drauge laiką. Kūdikiai po programos tapo aktyvesni, tai reiškèsi vokalizavimo, krykštavimo emocinemis reakcijomis. Vokalizacijų ir krykštavimo augimas atskleidžia, viena vertus, fiziologinę vaikų brandą, kuri pakito artimos situacinès interakcijos poveikyje, kita vertus, kokybiškai naujo bendravimo (bendravimo kalba) formavimąsi. 


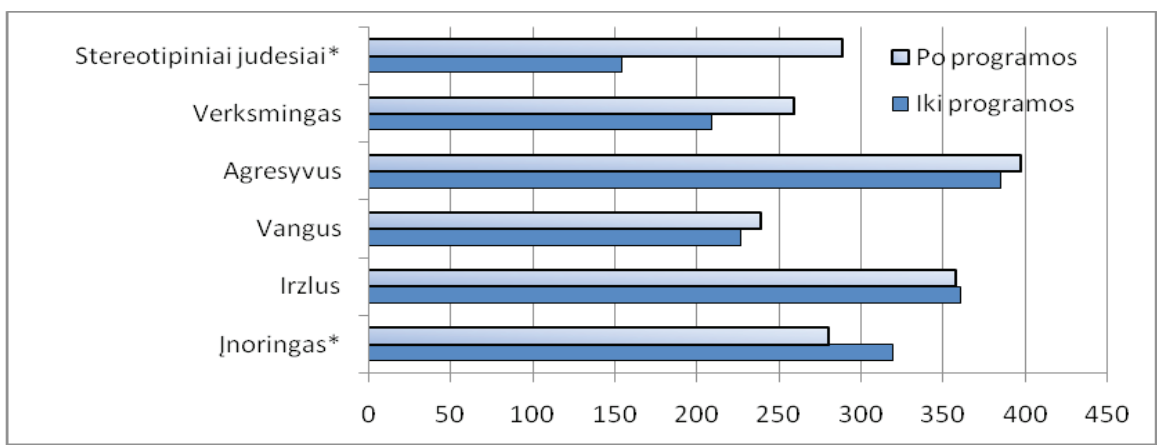

2 pav. Negatyvios vaikų elgsenos ir emocinès raiškos kaita

Pastaba: * elgsenos kategorijų statistiškai reikšmingas kitimas $p \leq 0,05$

Nepageidaujamos elgsenos fiksuota daugiau negu pageidaujamos ir iki programos, ir po jos. Tačiau dèl situacinès interakcijos poveikio kito ir netinkamos vaiko elgsenos formos (2 pav.). Tenka pastebèti, kad tyrime dauguma kūdikių demonstruotų neigiamų emocijų ar nepageidautinos elgsenos apraiškų didejo tačiau statistinio reikšmingumo nenustatyta. Reikšmingai mažèjo tik kūdikių įnoringumas $(p=0,02)$. Sutrikusios raidos kūdikių elgsenoje dažnai stebimi stereotipiniai judesiai. Pažymètina, kad po programos tėvai fiksavo ženklų šios elgsenos ryškẻjimą $(p=0,03)$. Liūdesio emocijos raiška ir kaita nebuvo tokios optimistiškos, kaip tikètasi. Vangumą, sunkiai numaldomą verksmą, apatiją, inertiškumą apibūdinome kaip liūdesio emocijos raišką, kuri apibrèžiama kaip nusiminimo jausmas, kylantis dèl ko nors stokos, netekties. Liūdesys reiškiasi sumenkejjusia veiklos motyvacija, pasyvumu, vangumu (Psichologijos žodynas, 1993). Tyrimo duomenų analizė atskleidè, kad raidos sutrikimų turinčių kūdikių liūdesio emocijos fiksuotos gana dažnai. Akivaizdu, kad ankstyvajame amžiuje liūdesio emocija neturètų būti fiksuojama kaip vyraujanti tam tikrą laiko tarpą, tačiau šiuo atveju, matyt, reikšminga yra negale ir jos nulemtas santykis su aplinka. Verksmas gali turèti daug priežasčių, tai tarsi pareiškimas juo besirūpinančiam suaugusiajam, kad kažkas vyksta ne taip, kaip vaikui norètųsi. Šeimoje vaikas verkia dèl to, kad tarp jo ir artimujų yra susiformavę (arba formuojasi) tam tikri emociniai ryšiai, ir tik pasitikèdamas artimu žmogumi vaikas verkdamas atkreipia suaugusiojo dèmesį, reiškia savo norus, su juo komunikuoja.

Pykčio emocijos kito labiau negu liūdesio. Šios emocijos raiška, palyginus su kitų emocijų, buvo menka, tačiau jos fiksavimas kaip kurị laiką vyraujančios emocijos atskleidžia, kad sutrikusios raidos vaikai, dažnai nesuprasti tèvų ar tiesiog neturėdami galimybių išreikšti savo poreikius, atsiduria konfliktinėse situacijose. 
Pykčio emocijos statistiškai reikšmingas skirtumas $(p=0,02)$ nustatytas tarp berniuku. Galima ir kita pykčio emocijos didejjimo interpretacija: vaikai igijo daugiau patirties, žinių, igūdžių ir šią vaikams malonią patirtị norètų pratęsti ar perkelti ị kitą veiklą.

Stereotipiniai judesiai dažnai ịvardijami kaip raidos sutrikimų turinčiu vaikų elgsenos bruožas, kuris dažnai siejamas su sensorine autostimuliacija, nerimo raiška ir pan. Dažnai stereotipiniai judesiai ankstyvajame amžiuje siejami su autizmu, tačiau jie, kaip vienas iš simptomų, gali lydèti ir daugelị centrinès nervų sistemos patologinių būklių. Tiek nerimas, tiek stereotipinių judesių kiltis yra ịvairi ir daugeliu atvejų sunkiai identifikuojama, ypač turint mintyje sutrikusios raidos ankstyvojo amžiaus vaikų elgsenos ypatumus. Nerimo emocija apibrèžiama kaip „neapibrèžtas grèsmès jausmas, kylantis dèl realaus ar ịsivaizduojamo pavojaus“ (Psichologijos žodynas, 1993, p. 181). Tyrimo duomenų analizė atskleidè, kad nerimo emocija nebuvo vyraujanti. Tai stabili ir emocine interakcija pagrịstam poveikiui pakankamai rezistentiška būklè (nors nustatytas reikšmingas pokytis $-p-0,01)$, tačiau pati savaime nerimo emocijos raiška nèra palankus faktas vaiko raidos proceso kontekste. Situacinès emocinės sąveikos suaktyvintos nerimo emocijos buvo neutralizuotos, patenkinant ne tik psichinius, bet ir pažintinius vaiko poreikius.

\section{Išvados}

1. Mokslo literatūros analizè atskleidè, kad raidos sutrikimų turinčiu ankstyvojo amžiaus vaikų bendravimo, emocinè, kartu ir prieraišumo raida nėra natūrali, nes pirmieji bandymai komunikuoti dèl sensorinès deprivacijos nėra adekvatūs, be to, kūdikiai negali adekvačiai ịvertinti tẻvų elgsenos, jiems siunčiamų signalų.

2. Vykdant tẻvams parengtą situacine interakcija pagrịstą bendravimo programą emocinè kūdikių raiška gali būti sèkmingai plètojama ne tik skatinant bendrają vaiko psichomotorinę raidą, bet ir siekiant išvengti auklèjimo klaidų, kurios formuojasi kaip antrinio pobūdžio raidos sutrikimo pasekmè.

3. Nustatyta, kad dèl situacinio interakcinio poveikio kūdikių emocinè raiška ir jų elgsena, bendraujant su tèvais, kito, apimdama platesnę emocijų skalę, tèvai greičiau ir tiksliau suprato vaiko poreikius, reiškiamus atitinkama elgsena ir emocijomis, tai sudare galimybes formuotis adekvatiems tẻvų ir kūdikio komunikacijos ịgūdžiams. 
4. Kūdikių demonstruota neigiama elgsena ir iki programos, ir jai pasibaigus leido atskleisti daugeli priežasčių, kurių viena ir gali būti netinkamai kūdikių atkoduojama gaunama informacija, kad yra susiformavę (arba formuojasi) tam tikri emociniai ryšiai, kurie neleidžia suaugusiajam teisingai atkoduoti vaiko psichofizinès būklès ir ị ją adekvačiai reaguoti.

Gauta 20140915

Pasirašyta spaudai 20141222

\section{Literatūra}

Ališauskienė, S. (2005). Ankstyvoji intervencija vaikystejje. Monografija. ŠUL.

Ališauskienè, S., Selvenytė, E. (2004). Tèvų pasitenkinimas ankstyvaja intervencija: lyginamoji situacijos analizė Europos šalių kontekste. Specialusis ugdymas 1 (10): 9-22.

Ankstyvoji intervencija vaikysteje. Europos situacijos analize. Esminiai aspektai ir rekomendacijos. Early Childhood Intervention in Europe. Key Aspects and Recommendations. (2005). V. Soriano (ed.). Prieiga internete: http://www.european-agency.org/eci/eci.html.

Benson, J. B., Haith, M. (2009). Social and Emotional Development in Infancy and Early Childhood. Academic Press.

Charles, H., Zeanah, Jr. (2012). Handbook of Infant Mental Health. Guilford Press.

DiMatteo, M. R. (2002). Health Psychology. Cambridge. MA: Perseus Publishing.

Dunst, C., Trivette, C., Hamby, D. (2008). Research synthesis and meta-analysis of studies of family-centered practices (Winterberry Press Monograph Series). Asheville, NC: Winterberry Press.

Eisenberg, N., Spinrad, T. (2004). Emotion-Related Regulation: Sharpening the Definition. Child Development 75 (2): 334-39.

Juffer, F., Bakermans-Kranenburg, M. J., Van Ijzendoorn, M. H. (2007). Promoting Positive Parenting: An Attachment-Based Intervention. Taylor \& Francis.

Kihlstrom, J. F. (2012). The Person-Situation Interaction. In: D. Carlston (ed.). Oxford Handbook of Social Cognition [a volume in the Oxford Library of Psychology]. New York: Oxford University Press.

Meisels, S. J., and others. (2003). The Ounce Scale: Standards for the Developmental Profiles (Birth-42 Months). New York: Pearson Early Learning.

Powell, D., Dunlap, G. (2010). Family-Focused Interventions for Promoting Social-Emotional Development in Infants and Toddlers with or at Risk for Disabilities. Roadmap to Effective Intervention Practices \#5.

Psichologijos žodynas. (1993).Vilnius: Mokslo ir enciklopedijų leidykla, p. 75-76.

Radzevičienè, L. (2006). Globos institucijose augančių kūdikių emociju raida. Monografija. Šiauliai: VšI Šiaulių universiteto leidykla. IBSN 9986-38-715-9, p. 229.

Radzevičienè, L.(2000). Early behavioral disorders of young emotionally abused infants. Sveikatos aplinka 3 : 25-30.

Robin, P., Troy, M. (2010). Disorders of Childhood: Development and Psychopathology Cengage Learning. Belmont: Wadsworth, Cengage Learning.

Tronick, E. (2007). The Neurobehavioral and Social-Emotional Development of Infants and Children. Norton Series on Interpersonal Neurobiology. WW Norton \& Co.

Zeanah, Ch. H. Jr. (2012). Handbook of Infant Mental Health. Guilford Press.

Изард, К. (2000). Психология эмоций. Санкт-Петербург: Питер, с. 15-39; 42-107. 


\section{EMOTIONAL EXPRESSION AND IT'S DEVELOPMENT IN FAMILY OF EARLY AGE CHILDREN HAVING EVOLUTIONAL DISORDER}

\section{Liuda Radzevičienė, Nijolė Šostakienė}

Summary

Changes that took part in recent decades in the area of understanding of Early Intervention emphasizes shift from child oriented intervention to more universal point of view. Involvement of family highlights sharing of support and active family's' participation in the organizational of interventions Such model is more effective in the aspects of dynamic of child development as well as in the aspect parents empowering in the interventional activities.

Object of the research: Emotional Expression and its Development in Family of Early Age Children Having Developmental Disorders

Aim of the research: To reveal emotional expression and its development in family of early age children having developmental disorders applying program of situational interaction.

Methodological background of family oriented program of situational interaction.

Cognitive approach to the social interaction starts from axiom that human is sensible being whose behavior is not incidental, conditioned by reflexes or instincts (Eisenberg, Spinrad, 2004; Juffer, Bakermans-Kranenburg, Van Ijzendoorn, 2007; Powell, Dunlap, 2010). Response to the environmental stimulation have cognitive meaning and this does human behavior socially adequate (Kihlstrom, 2012). So situational interactions in the society are understandable as social interactions, and in the context of individual communication they could be understood as situational interactions, it means that they are more constricted, spontaneous, flexible, and more particular type of communication. Sustainability of situational interaction program emphasizes forms of parents - child's behavior that significant for the dynamics of child's development (Juffer, Bakermans-Kranenburg, Van Ijzendoorn, 2007; Powell, Dunlap, 2010).

Methods and proceeding of the research: analysis of the scientific materials; During 4 weeks observation and recording of child emotional expressions in the family in order to identify emotions according to the patterns of child's behavior; Purposeful observation: on the base of observation results, protocol for purposeful observation was arranged were child's behavior was fixed according to the aspects of day time and duration; Situational interaction program that continues nine 
months was devoted to the development of emotional expressiveness of early age children who have developmental disorders.

34 families who are bringing up early age children with developmental disorders took place in the research and the same number of infants from the age of 16 to 24 months. Diagnosis of developmental disorder was certified by medical conclusions. Families that attend in the $\mathrm{N}$ region Early Intervention services participated in the research unconstrained.

Analysis of the research indicated that there are not enough scientific materials concerning emotional expressiveness of early age children having developmental disorders and peculiarities of their interaction with parents. For the children who have developmental disorders situational interaction with parents in most cases is effective and it develops positive characteristics of parents - child's interaction patterns. Negative patterns of child's behavior were fixed before program as well as after program. Frequency of negative emotional reaction increased but not significantly. It could be related with child health conditions. Activated by program emotions of anxiety were neutralized satisfying children not only psychical but cognitive needs as well. 
